A

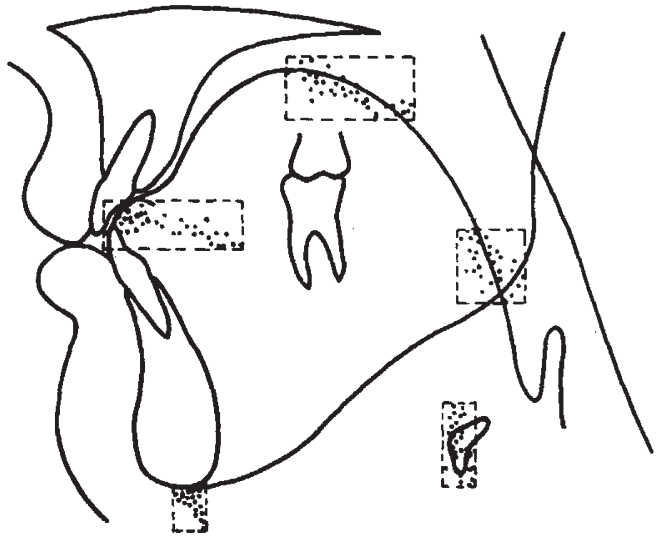

B

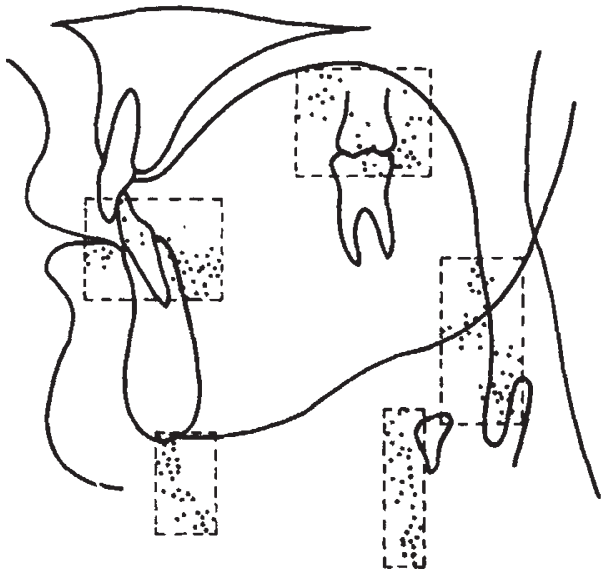

Fig. 2 Two subjects (A and B) showing variation in the range of movements of the mandible, tongue and hyoid in speech as determined by analysis of high speed cineradiographic records.

Further work suggests that these relationships between structure and function become more obvious if movement patterns are related not only to intermaxillary space size, but also to the available space in which the tongue performs its adaptive functions for the production of speech. Such differences in the amount and direction of movements used for speaking suggest that individuals vary in the total effort necessary for the production of acceptable speech sounds. Variations in the total expenditure of effort associated with differing amounts and directions of movement will affect not only the ease with which a particular sound is produced, but will obviously condition the facility for the production of certain sequences of movement for the production of continuous or connected speech.

The presence of phonemes such as dental or pharyngeal fricatives varies in the languages of man. Likewise, certain sequences of sounds occur in the speech of some populations but not in others. It is therefore probable that population differences in genotype are manifested in characteristic frequency distributions of intermaxillary space dimensions which determine the sounds and their sequential organization in language. Changes in populations affecting their gene-pool will tend to produce variations in the distribution of genotypes. Through such changes the sounds of language may alter to accommodate the articulatory preference of the changing community.

Peter S. Vio

The London Hospital Medical College Dental School,

Turner Street, London E1

Received November 19, 1971.

${ }^{1}$ Darlington, C. D., Heredity, 1, 269 (1947).

2 Brosnahan, L. F., The Sounds of Language (Heffer, Cambridge, 1961).

${ }^{3}$ Huber, E., Quart. Rev. Biol., 5, 133 (1930).

4 Sturtevant, A. H., Proc. US Nat. Acad. Sci., 26, 100 (1940).

5 Ballard, C. F., Dent. Practit., 8, 42 (1957).

${ }^{6}$ Ballard, C. F., Trans. Europ. Orthod. Soc., 67 (1963).

'Ballard, C. F., and Bond, E. K., Speech Pathol. and Ther., 3, 55 (1969).

${ }^{8}$ Vig, P., Trans. Brit. Soc. Study Orthod., 76 (1969).

Vig, P., thesis, Univ. London (1968).

\section{Do Fossil Elephants date the South African Australopithecines?}

Wolpoff has recently proposed a date of $4.0 \mathrm{~m} . \mathrm{y}$. for the South African australopithecines ${ }^{1}$. He used, however, two stratigraphic correlations which cannot be justified: (1) Cooke's original correlation ${ }^{2}$ of Sterkfontein, Makapansgat and Taung (=Sterkfontein Faunal Span) with the Vaal Basal Older
Gravels, and (2) Maglio's provisional correlation ${ }^{3}$ of fossil elephants from the "Vaal River gravels" with Kanapoi species " $C$ ", radiometrically dated at $4.0 \mathrm{~m} . \mathrm{y}$. Wolpoff assumed (ref. 1, page 579) that Maglio's ambiguous term "Vaal River gravels" referred to "the beginning of the Vaal River sequence (oldest gravels)", and hence assumed a correlative date of 4.0 m.y. for the Sterkfontein Faunal Span and associated australopithecines.

The palaeontological literature for the Vaal River $^{4,5}$ reveals that the elephant-bearing deposits are assigned to the Younger Gravels which are Middle Pleistocene in age. Furthermore, Maglio (ref. 3, page 331) writes: "The type and only specimen of each Vaal River species is insufficient for adequate specific definition". Hence, there is no evidence that the Vaal River fossil elephants are conspecific with Kanapoi species "C" or that they have a date of $4.0 \mathrm{~m} . \mathrm{y}$.

Mason notes (ref. 6, page 40) that "the Basal Older Gravels and Older Gravels lack animal or human fossils". Without fossil material, no correlations between these two gravel formations and the South African cave sites are possible. Cooke $^{7}$ apparently no longer feels that a Basal Older GravelsSterkfontein Faunal Span correlation is valid; it does not appear on his latest chronology chart. He still, however, equates the Sterkfontein Faunal Span with Olduvai Bed I at about 1.9-1.25 m.y.

In sum, the fossil elephants do not assist the dating of South African australopithecines because (1) the Younger Gravels from which the elephants in question were derived are Middle Pleistocene in age; and (2) the Basal Older Gravels are sterile of elephants or other fauna which might be used to correlate this deposit with the Sterkfontein Faunal Span. Furthermore, australopithecine sites in South Africa lack associated elephant material.

GARY A. WRIGHT

Department of Anthropology, State University of New York, Albany, New York

Department of Anthropology,

SUZANne SKaryd

Case Western Reserve University, Cleveland, Ohio

Received March 15; revised November 22, 1971.

1 Wolpoff, M. H., Amer. Anthrop., 72, 576 (1970).

2 Cooke, H. B. S., in African Ecology and Human Evolution (edit. by Howell, F. C., and Bourliere, F.), 65 (Methuen, London, 1963).

3 Maglio, V. J., Nature, 225, 328 (1970).

4 Dart, R. A., S. Afr. J. Sci., 26, 698 (1929).

3 Cooke, H. B. S., Mem. Geol. Surv. Un. S. Afr., 35 (3), 1 (1949).

6 Mason, R., The Prehistory of the Transvaal (University of Witwatersrand Press, 1962).

7 Cooke, H. B. S., Quart. Rev. Biol., 43, 234 (1968). 